\title{
The Coexistence of Chronic Lymphocytic Leukemia and Multiple Myeloma
}

\author{
Kronik Lenfositik Lösemi ve Multipl Myelom Birlikteliği
}

(D) Ceren Hangül1, (D) Orhan Kemal Yücel2 ${ }^{2}$, (D) Bahar Akkaya ${ }^{3}$, (D) Levent Ündar², (D) Sibel Berker Karaüzüm¹

${ }^{1}$ Akdeniz University Faculty of Medicine, Department of Medical Biology and Genetics, Antalya, Turkey

${ }^{2}$ Akdeniz University Faculty of Medicine, Department of Hematology, Antalya, Turkey

${ }^{3}$ Akdeniz University Faculty of Medicine, Department of Pathology, Antalya, Turkey

To the Editor,

Multiple myeloma (MM) and chronic lymphocytic leukemia (CLL) are neoplastic diseases originating from different stages of B-cell maturation. The coexistence of $\mathrm{MM}$ and $\mathrm{CLL}$ in the same patient is quite rare [1]. Here we report a patient with CLL who later developed kappa light chain MM.

A 67-year-old male was diagnosed with CLL with CD5+, CD19+, CD23+ B lymphocytes detected by flow cytometry. Karyotype analysis revealed $45, X, Y[4] / 46, X Y[10]$ and $55 \%$ deletion of 11 q22.3 was found as the sole anomaly by fluorescence in situ hybridization (FISH). He was treated with chlorambucil and dexamethasone.

Five years later, he was admitted with fatigue, back pain, hypercalcemia, and acute renal failure. There was no palpable lymphadenopathy or hepatosplenomegaly. Serum and urine immunofixation electrophoresis revealed kappa light chain monoclonal protein, while bone marrow (BM) aspiration revealed at least 30\% atypical plasma cells. Similarly, BM immunophenotyping revealed 30\% clonal plasma cells (CD38+,
CD138+) and approximately $1 \%$ residual CLL cells. The complex karyotype was found as $46, X Y, \operatorname{der}(6) \mathrm{t}(1 ; 6)(q 11 ; q 23), \mathrm{t}(11 ; 14)$ (q13;q32),dup(17)(q23q25)[17]/46,XY[2] (Figure 1). FISH analysis revealed $\mathrm{t}(11 ; 14)$ and deletion $6 \mathrm{q} 23$, but not the prior $11 \mathrm{q} 22.3$ deletion. He was diagnosed with MM. Intravenous hydration, plasmapheresis, furosemide, pamidronate, and dexamethasone were started. Following discharge from the hospital, he was lost to follow-up.

The coexistence of CLL and MM is quite rare and there is controversy as to whether the two diseases arise from the same clone or distinct clones. Fermand et al. [2] showed that these malignancies came from the same clone by the identification of Ig idiotypes. After CLL cells were exposed to mitogens and allogenic T cells, a class switch from IgG to IgA was observed, showing that CLL cells can be precursors of plasma cells. Brouet et al. [3], Novak et al. [4], and Kaufmann et al. [5] showed Ig molecules synthesizing different light chains, revealing the coexistence of two distinct clones. However, Ig subtyping cannot always eliminate clonality. In some cases CLL and MM are diagnosed together, whereas in others MM is diagnosed
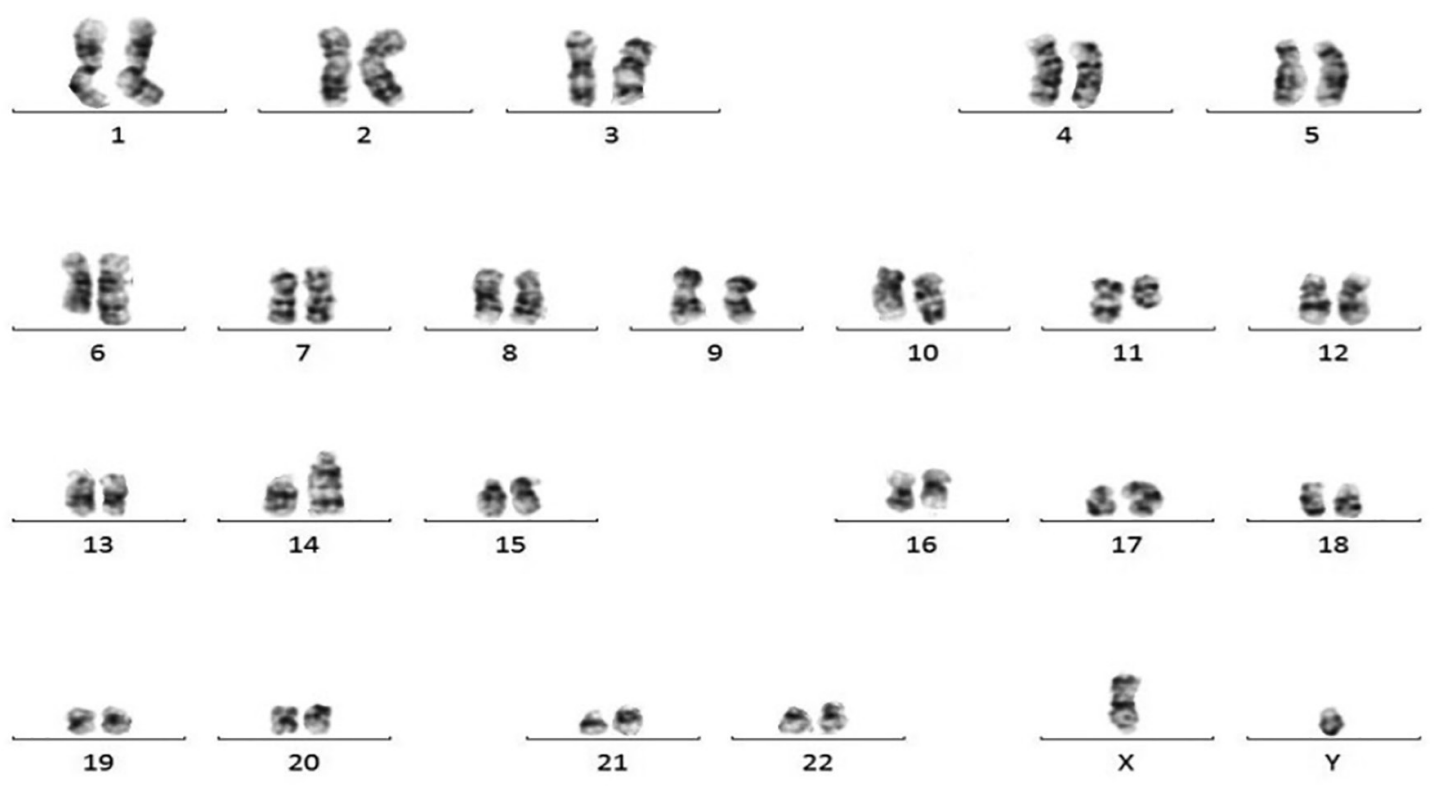

Figure 1. Karyotyping analysis showing 46,XY,der(6)t(1;6)(q11;q23),t(11;14)(q13;q32),dup(17)(q23q25)[17]/46,XY[2] (94x64 mm; 72x72 DPI). 
1-15 years after CLL. Barlogie and Gale [6] indicated a difference in pathophysiology; in CLL, most tumor B cells are inert and arrested in the $\mathrm{G0} / \mathrm{G} 1$ phase, whereas in MM there is an increase in proliferation with stromal cell cytokines like IL-6. In our case, there was ATM deletion at the time of the CLL diagnosis, but not at MM diagnosis, indicating multiclonality.

Compatible with our case, there are reported cases of patients diagnosed with MM after CLL who had chromosome 11 anomalies at the time of the CLL diagnosis [7], raising the following question: Could some of the chromosome 11 anomalies be related to transformation from CLL to MM, and used as a predictor? To clarify the role of these genetic, epigenetic $[8,9]$, or microenvironmental factors for the coexistence of two diseases, more case reports are needed.

\section{Acknowledgments}

This study was supported by the Akdeniz University Scientific Research Management Foundation.

Keywords: Chronic lymphocytic leukemia, Multiple myeloma, Hematological malignancy, Clonality

Anahtar Sözcükler: Kronik lenfositik lösemi, Multipl myelom, Hematolojik malignensi, Klonalite

Informed Consent: It was received.
Conflict of Interest: The authors of this paper have no conflicts of interest, including specific financial interests, relationships, and/or affiliations relevant to the subject matter or materials included.

\section{References}

1. Kough RH, Makary AZ. Chronic lymphocytic leukemia (CLL) terminating in multiple myeloma: report of two cases. Blood 1978;52:532-536.

2. Fermand JP, James JM, Herait P. Associated chronic lymphocytic leukemia and multiple myeloma: origin from a single clone. Blood 1985;66:291-293.

3. Brouet JC, Fermand JP, Laurent G, Grange MJ, Chevalier A, Jacquillat C, Seligmann M. The association of chronic lymphocytic leukemia and multiple myeloma: a study of eleven patients. Br J Haematol 1985;59:55-66.

4. Novak PM, Mattson JC, Crisan D, Chen J, Poulik MD, Decker D. Separate clones in concomitant multiple myeloma and second B-cell neoplasm demonstrated by molecular and immunophenotypic analysis. Eur J Haematol 1995;54:254-261.

5. Kaufmann $H$, Ackermann J, Nösslinger T, Krömer E, Zojer N, Schreiber $\mathrm{S}$, Urbauer $\mathrm{E}$, Heinz $\mathrm{R}$, Ludwig $\mathrm{H}$, Huber $\mathrm{H}$, Drach J. Absence of clonal chromosomal relationship between concomitant B-CLL and multiple myeloma - a report on two cases. Ann Hematol 2001;80:474-478.

6. Barlogie B, Gale RP. Multiple myeloma and chronic lymphocytic leukemia: parallels and contrasts. Am J Med 1992;93:443-450.

7. Pantic M, Schroettner P, Pfeifer D, Rawluk J, Denz U, Schmitt-Gräff A, Veelken $\mathrm{H}$, Wäsch $\mathrm{R}$, Engelhardt M. Biclonal origin prevails in concomitant chronic lymphocytic leukemia and multiple myeloma. Leukemia 2010;24:885-890.

8. Dimopoulos K, Gimsing P, Gronbaek K. The role of epigenetics in the biology of multiple myeloma. Blood Cancer J 2014;4:e207.

9. Martín-Subero Jl, Lopez-Otin C, Campo E. Genetic and epigenetic basis of chronic lymphocytic leukemia. Curr Opin Hematol 2013;4:362-368.

๑Copyright 2019 by Turkish Society of Hematology

Turkish Journal of Hematology, Published by Galenos Publishing House

Address for Correspondence/Yazışma Adresi: Ceren HANGÜL, M.D.,

Akdeniz University Faculty of Medicine, Department of Medical Biology and Genetics,

Antalya, Turkey

Phone : +902422449697

E-mail : cerenhangul@hotmail.com - sibelberkerkarauzum@gmail.com

ORCID-ID: orcid.org/0000-0001-6869-8802
Received/Geliş tarihi: March 12, 2018

Accepted/Kabul tarihi: June 20, 2018

DOI: 10.4274/tjh.galenos.2018.2018.0096 